\title{
Geologia
}

\section{Aspectos Tectônicos das Intrusões dos Granitos do Cerne, Passa Três e Rio Abaixo, Sudeste do Pré-cambriano Paranaense. Estudo Baseado em Datações ${ }^{39} \mathrm{Ar}-{ }^{40} \mathrm{Ar}$ em Micas}

\author{
Leonardo Fadel Cury’ (Ifcury@igc.usp.br), Oswaldo Siga Jr.2 (osigair@usp.br), \\ Ossama Mohamed Milad Harara3 (ommh@hotmail.com), Helcio José dos Prazeres Filho' (prazeres@usp.br), \\ Miguel Angelo Stipp Basei² (baseimas@usp.br) \\ Programa de Pós-graduação em Geoquímica e Geotectônica - Instituto de Geociências - USP \\ R. do Lago 562, CEP 05508-080, São Paulo, SP, BR \\ ${ }^{2}$ Departamento de Mineralogia e Geotectônica - Instituto de Geociências - USP, São Paulo, SP, BR \\ ${ }^{3}$ Departamento de Geologia - Setor de Ciências da Terra - UFPR, Curitiba, PR, BR
}

Recebido em 18 de setembro de 2007; aceito em 20 de março de 2008

Palavras-chave: Domínio Apiaí, magmatismo tardi-tectônico, datações ${ }^{40} \mathrm{Ar}-{ }^{39} \mathrm{Ar}$ em micas.

\section{RESUMO}

Os stocks graníticos do Cerne, Passa Três e Rio Abaixo são representados por corpos elípticos, alongados segundo NE-SW (granitos do Cerne e Passa Três) e com formas “ovóides” (Granito Rio Abaixo), intrusivos nas seqüências metavulcanossedimentares da porção sudeste do Cinturão Ribeira, no Estado do Paraná. Esses corpos são representados principalmente por biotitasienogranitos, monzogranitos e quartzo-sienitos porfiríticos, com megacristais de microclínio, isótropos ou com foliação de fluxo magmático, podendo apresentar termos deformados em regiões restritas às zonas de contato. Mostram afinidades petrológicas, geoquímicas e geocronológicas, com características semelhantes aos granitos tipo-A, porém, enriquecidos em Ba, Sr e Zr. Análises ${ }^{40} \mathrm{Ar}-{ }^{39} \mathrm{Ar}$ em biotitas do Granito do Cerne indicaram idade integrada de $557 \pm 2 \mathrm{Ma}$, valor este relativamente próximo à idade de cristalização dos zircões de aproximadamente 563 Ma, definida por Cury (2003). Determinações ${ }^{40} \mathrm{Ar}-{ }^{39} \mathrm{Ar}$ obtidas em rochas encaixantes (muscovitas xistos) das vizinhanças do Granito do Cerne apresentam idades mais antigas (800-1200 Ma), o que permite concluir que a intrusão do granito, bem como o evento metamórfico regional ocorrido durante o Ciclo Brasiliano, não atingiram temperaturas suficientes para apagar o registro isotópico das muscovitas $\left(\mathrm{T}<300^{\circ} \mathrm{C}\right)$. Os stocks graníticos do Cerne, Passa Três e Rio Abaixo representam magmatismo tardi-orogênico no contexto das deformações presentes no Domínio Apiaí e ao arco-magmático Três Córregos-Cunhaporanga (630-590 Ma), relacionado aos estágios finais de transpressão, onde sua colocação é intimamente associada às zonas de cisalhamento transcorrente e desenvolvimento das grandes antiformas e sinformas. Tal período (Proterozóico Superior/Cambriano) representa um importante marco na região, associado aos ajustes finais relacionados à aglutinação do Supercontinente Gondwana.

Keywords: Apiaí Domain, late-tectonic magmatism, ${ }^{39} \mathrm{Ar}-{ }^{40} \mathrm{Ar}$ dating of micas.

\section{ABSTRACT}

The Cerne, Passa Três and Rio Abaixo granitic stocks are NE-SW-striking elliptic bodies intrusive in the metavolcanosedimentary sequences of the southeastern portion of the Ribeira Belt (Paraná State, Brazil). These stocks are mainly biotite syenogranite, monzogranite and quartz-syenite with porphyritic textures containing microcline megacrystals. They are usually isotropic, but may also contain magmatic flow foliation and deformation restricted to the contact with the host rocks. These granites present petrological, geochemistries and geocchronological similarities, with many A-type characteristics, but they are enriched in $\mathrm{Ba} \mathrm{Sr}$ and $\mathrm{Zr} .{ }^{40} \mathrm{Ar}-{ }^{39} \mathrm{Ar}$ analyses of the Cerne Granite biotites indicate an integrated age of $557 \pm 2 \mathrm{Ma}$, which is quite close to the lower Concordia intercept age interpreted as the crystallization age of about 563 Ma obtained by TIMS analysis of zircon from the Cerne and Rio Abaixo intrusions by Cury (2003). The ${ }^{40} \mathrm{Ar}^{-39} \mathrm{Ar}$ determinations in the host muscovite schists 
from the vicinity of the Cerne granite are older (800-1200 Ma) than crystallization ages, indicating that the temperatures of the granite intrusion and of the regional metamorphic event that took place during the Brasiliano Cycle (c.a. $600 \mathrm{Ma}$ ) were not high enough to erase the isotopic record from these muscovites $\left(\mathrm{T}<300^{\circ} \mathrm{C}\right)$. These granitic stocks represent a late-orogenic magmatism $(\sim 560 \mathrm{Ma})$ in the context of the deformations phases registered in the Apiaí Domain, being different and subsequent to the event of Três Córregos - Cunhaporanga magmatic arc (c.a. 630-590 Ma). Their emplacement was closely associated with transcurrent shear zones and the development of the major antiforms and synforms during the Upper Proterozoic/Cambrian, associated with the final adjustments of the agglutination of the Gondwana Supercontinent.

\section{INTRODUÇÃO}

Os diversos trabalhos sobre a geologia do Pré-cambriano paranaense expressam a grande complexidade desses terrenos, caracterizados pela sobreposição de sucessivos eventos tectônicos ao longo de sua história evolutiva. O estilo estrutural e o grau metamórfico são importantes critérios para diferenciar as grandes unidades litoestratigráficas da região. Porém, nem sempre esses critérios são conclusivos, tendo em vista a possibilidade de duas unidades diferentes possuírem semelhanças, ou então, uma só unidade apresentar variações de estilo estrutural e grau metamórfico. Frente a esse contexto, a geocronologia tem se mostrado uma eficiente ferramenta para distinguir e caracterizar as diferentes unidades litoestratigráficas do Pré-cambriano paranaense, bem como para determinar os diferentes eventos de deformação e metamorfismo.

O presente estudo busca detalhar as condições tectônicas de instalação dos stocks graníticos Cerne, Passa Três e Rio Abaixo, a fim de revelar uma importante fase da história evolutiva desses terrenos, mediante a caracterização do regime e da época de sua colocação, além da comparação com o registro estrutural e geocronológico das rochas encaixantes (estruturas vs. idades de metamorfismo ${ }^{40} \mathrm{Ar}-{ }^{39} \mathrm{Ar}$ micas).

\section{CONTEXTO REGIONAL}

A geologia do Pré-cambriano paranaense foi intensamente estudada e amplamente discutida desde o século passado em mais de uma centena de trabalhos e relatórios publicados. O quadro gerado chegou a ser confuso e fragmentário, caracterizado por inúmeras propostas de empilhamentos estratigráficos, modelos evolutivos e proliferação de denominações, muitas das quais oriundas de trabalhos localizados, contraditórios às normas estratigráficas.

No âmbito regional, merecem destaque os trabalhos de mapeamento realizados nas décadas de 60 e 70 pela Comissão da Carta Geológica do Paraná (CODEPAR), Projeto Leste do Paraná (CPRM), Projeto Sudeste do Estado de São Paulo (CPRM), Projeto Ribeira, Projeto de Integração e Detalhe do Vale do Ribeira e Projeto Anta-Gorda. Também merecem destaque os trabalhos de Hasui et al. (1975), JICA/
MMAJ (1982), Hasui (1986), Ebert et al. (1988), Soares (1987), Fiori (1990, 1992), Basei et al. (1992), Fiori e Gaspar (1993), Daitx (1996), Fassbinder (1996), Soares e Rostirolla (1997), Hackspacher et al. (1997), Wernick (1997, 1998a, 1998b) e Campanha e Sadowski (1999), que abordam, de modo integrado, estudos relacionados a ambientes de sedimentação, metamorfismo, plutonismo e vulcanismo, caracterização estrutural, geofísica, geocronologia e compartimentação tectônica. Na última década, estudos geocronológicos envolvendo principalmente os métodos U-Pb (zircão), Sm-Nd (rocha total) e K-Ar (minerais) permitiram grande avanço no quadro tectônico deste setor, com destaque para Kaulfuss (2001), Cury et al. (2002), Basei et al. (2003), Prazeres Filho et al. (2003), Siga Jr. et al. (2003) e Weber et al. (2003).

\section{Magmatismo intrusivo}

Corpos graníticos de naturezas diversas são conhecidos no setor sudeste paranaense, no âmbito do Domínio Apiaí, individualizados em projetos de mapeamento geológico básico, dentre os quais destacam-se os executados na década de 1960 pela Comissão da Carta Geológica do Paraná. Esses maciços possuem dimensões variadas, de stocks a batólitos, cujas denominações têm por base a toponímia das regiões onde ocorrem, por exemplo: Três Córregos, Cunhaporanga, Cerne, Passa Três, Rio Abaixo etc. (Figura 1).

\section{Complexos graníticos Três Córregos e Cunhaporanga}

O Complexo Três Córregos (Fuck et al., 1967; CPRM, 1977) constitui a maior intrusão granítica no sul do Brasil (CPRM, 1977) com aproximadamente 95 km de comprimento por 25 km de largura, com eixo maior na direção NE-SW. Os principais litotipos desse complexo são descritos como tonalitos, granodioritos a monzogranitos porfiríticos (por vezes deformados) e quartzo-monzonitos a monzogranitos porfiríticos (Prazeres Filho, 2000; Guimarães, 2000; Gimenez Filho, 1993).

O Complexo Cunhaporanga (Fuck et al., 1967; Algarte e Kaefer, 1972) ocupa a porção setentrional da Faixa Itaiacoca e também possui uma orientação preferencial NE-SW. É representado principalmente por rochas graníticas e granito- 


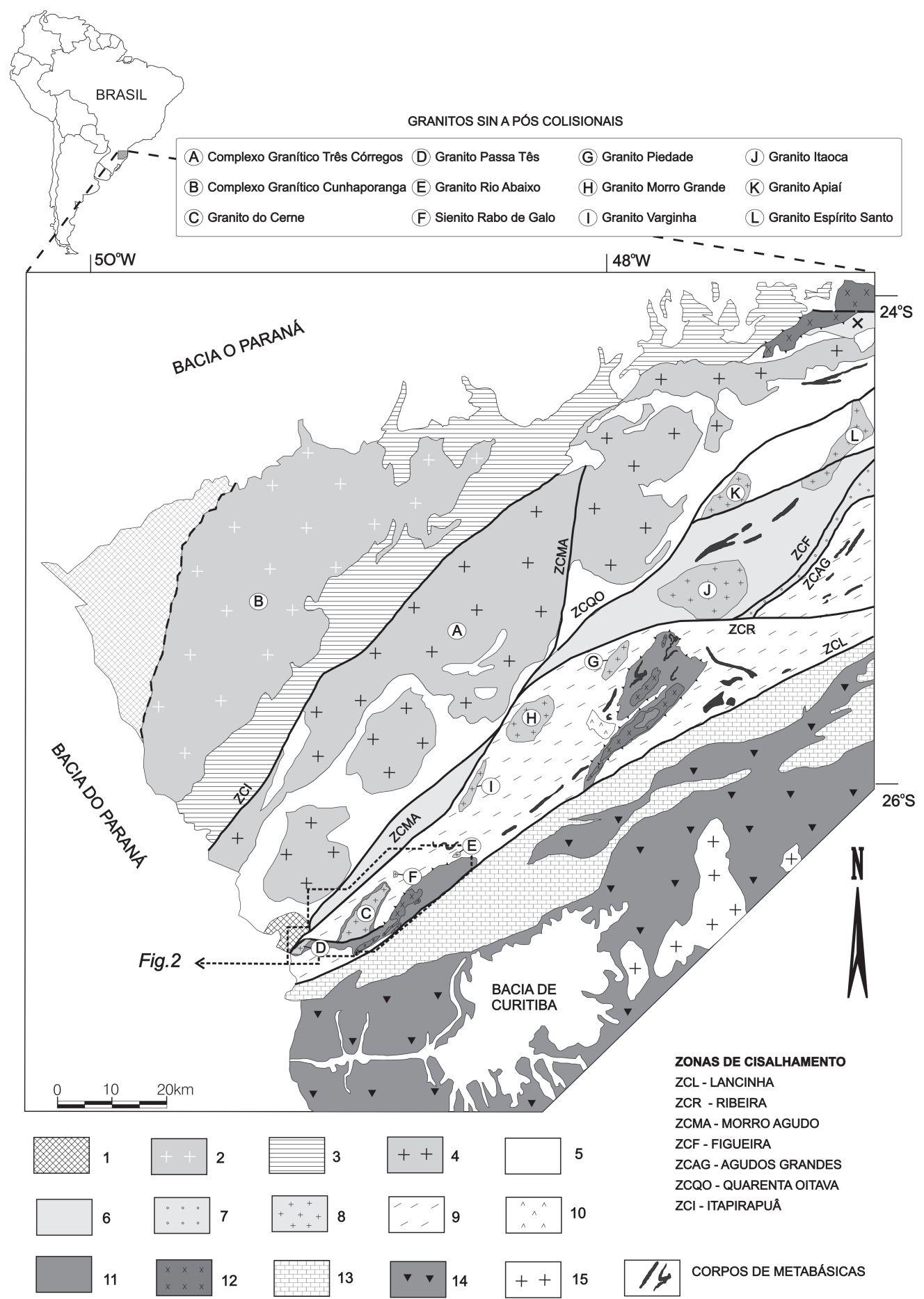

Figura 1. Esquema das principais unidades geológicas e tectônicas do sudeste brasileiro (adaptado de Siga Jr. et al., 2002). 1. Bacias de Ante-País [Grupo Castro (NW) e Grupo Camarinha (SW)]. 2. Batólito Cunhaporanga (600-590 Ma). 3. Grupo Itaiacoca (Neoproterozóico). 4. Batólito Três Córregos e corpos graníticos associados (630-600 Ma). 5. Formação Água Clara (c. 1450 Ma). 6. Seqüências Lajeado e Antinha (Neoprot.?). 7. Formação Iporanga (Neoproterozóico). 8. Granitóides sin- a pós-colisionais (590-570 Ma). 9. Formação Votuverava (c. $1450 \mathrm{Ma}$ ). 10. Sienito Tunas (85 Ma). 11. Seqüências Perau e Betara (1450 Ma). 12. Granitóides alcalinos deformados (1750 Ma) e granitóides cálcico-alcalinos deformados (2100 Ma). 13. Formação Capirú. 14. Complexo Gnáissico-Migmatítico Atuba. 15. Província Graciosa. 
gnáissicas. Suas principais variedades litológicas compreendem biotita-monzogranitos, biotita-monzogranitos porfiríticos, e anfibólio-biotita-monzogranitos (Prazeres Filho, 2000; Guimarães, 2000; Gimenez Filho, 1993).

Prazeres Filho (2000), mediante a uma análise conjunta dos dados geoquímicos e geocronológicos dos complexos Três Córregos e Cunhaporanga, sugere tratarem-se de maciços multiintrusivos, cálcio-alcalinos, gerados em ambiente compressional associado ao Ciclo Brasiliano. Atualmente o autor reconhece a presença de alguns granitos de ocorrência subordinada dentro desses complexos, não relacionados ao arco-magmático (Prazeres Filho et al., 2003).

Embora Soares (1987), Fiori (1990), Campanha (1991), Basei et al. (1992, 1997) e Reis Neto (1994) proponham modelos tectônicos diferentes, os mesmos concordam em considerar estes complexos como representantes de dois arcos magmáticos distintos. Prazeres Filho (2000) sugere a gênese dos mesmos como produto de um único arcomagmático, com migração para oeste. Fassbinder (1996) propõe um modelo tectônico alternativo para o Complexo Três Córregos, segundo o qual seria vinculado a um cinturão transpressivo, com ascensão do magma durante a fase transtrativa.

\section{Outros maciços graníticos}

São representados pelos granitos Apiaí, Itaoca, Espírito Santo, Piedade, Morro Grande, Varginha, Barra do Santana, Joaquim Murtinho, Serra do Carambeí, Cerne, Passa Três, Rio Abaixo, Monzonito Chacrinha e Sienito Rabo de Galo (Capivara), dentre outros corpos menores. Esses maciços são intrusivos nas seqüências metavulcanossedimentares do Domínio Apiaí (Siga Jr. et al., 2006), compostas por filitos, xistos, metamargas, metavulcânicas ácidas e básicas, quartzitos e metacalcários, metamorfisados na fácies xistoverde. São classificados como stocks, em sua maioria elípticos, com a direção do maior eixo concordante com a estruturação geral do Domínio Apiaí (NE-SW). Segundo Fiori (1990) muitos desses corpos estão instalados em antiformas, originadas pela movimentação dextral das zonas de cisalhamento Lancinha e Morro Agudo, ou falhas associadas. $\mathrm{O}$ autor sugere que as intrusões são contemporâneas ao desenvolvimento das zonas de cisalhamento, com deformação em condições ainda dúcteis.

\section{Granito Apiaí}

Este maciço é composto por monzogranitos porfiríticos e é intrusivo na Seqüência Votuverava, nas proximidades do município de Apiaí - SP. Sua gênese tem sido relacionada ao magmatismo tardi-colisional na Faixa de Dobramentos Apiaí (Mecher et al., 1973; Hackspacher et al., 2000).
Datações U-Pb (zircão) realizadas por Hackspacher et al. (2000) indicam a idade de cristalização de $605 \pm 4$ Ma. A idade modelo (TDM) de 2,36 Ga deste stock indica derivação a partir da litosfera durante o Paleoproterozóico tardio (Hackspacher et al., 2000).

\section{Granito Itaoca}

O Granito Itaoca (Melcher et al., 1973; Landin et al., 1979; Chiodi Filho et al., 1989) localiza-se entre os Estados de São Paulo e Paraná, cobrindo cerca de 200 km² e é intrusivo nas rochas metassedimentares da Seqüência Lajeado. Este maciço é composto por monzogranitos porfiríticos de alto potássio (shoshonitos) e múltiplas unidades granitóides consideradas como injeções co-genéticas, derivadas da crosta inferior (Mello e Bettencourt, 1998).

A colocação do Granito Itaoca foi controlada pela deformação transpressiva regional, associada aos sistemas transcorrentes e dobramentos correlatos, sendo considerada com sin- a tardi-tectônica em relação ao episódio deformacional do Neoproterozóico (Ciclo Brasiliano).

Este maciço contém depósitos de wollastonita e scheelitapowellita associados a skarns, localizados em sua porção central, formados durante os estágios de metassomatismo e hidrotermalismo (Mello e Bettencourt, 1998).

\section{Granito Espírito Santo}

O Granito Espírito Santo aflora como um corpo alongado, sendo composto predominantemente por monzogranitos e granodioritos porfiríticos. É intrusivo em rochas metassedimentares da fácies xisto-verde, provocando metamorfismo termal em regiões restritas à borda.

\section{Granito Piedade}

Trata-se de corpo elíptico e eixo maior orientado segundo N45E, intrusivo nas seqüências metavulcanossedimentares da Formação Votuverava. Chiodi Filho et al. (1989) e Spoladore (1993) descrevem domínios com predominância de álcali-granitos e álcali-sienitos, com ocorrência esparsa de microgranitos tardios ao magmatismo principal.

Segundo Spoladore (1993), os contatos desse corpo, a leste, são zonas de cisalhamento transcorrentes enquanto que, a oeste, a relação com as encaixantes é por metamorfismo de contato. Devido à forma do corpo e suas relações de contato com as encaixantes, o autor o considera sin-cinemático ao evento de transcorrência da região.

Com base em dados geoquímicos Chiodi Filho et al. (1987) interpreta que o magma primário originou-se no manto superior, com contaminação de crosta inferior. 


\section{Granito Morro Grande}

O Granito Morro Grande (CODEPAR, 1967) cobre aproximadamente $70 \mathrm{~km}^{2}$, com forma elipsoidal orientado segundo a direção NE-SW. Este granito está alojado em rochas da Formação Votuverava, em contatos com formação de auréolas de metamorfismo da fácies albita-epidoto-hornfels (Prazeres Filho, 2000).

Segundo Prazeres Filho (2000), é composto por monzo e sienogranitos que, em diagramas discriminantes de Pearce et al. (1984), plotam preferencialmente no limite entre granitóides de arco-magmático e intraplaca.

\section{Granito Varginha}

O Granito Varginha (CODEPAR, 1967) abrange $25 \mathrm{~km}^{2} \mathrm{e}$ está localizado entre as cidades de Tunas e Adrianópolis, no estado do Paraná. É composto principalmente por monzogranitos e subordinadamente por sienogranitos e quartzo-monzonitos, equigranulares, médios a grossos, predominantemente maciços ou com textura cataclástica e milonítica em sua porção norte (Fuck et al., 1967). Chiodi Filho (1989), por meio de análise de elementos terras raras, sugere uma mistura de fontes crustais e mantélicas para gênese desse granito.

\section{Granito Barra do Santana}

Também denominado de Granito Taici (Martini, 1982), constitui um corpo de dimensões reduzidas $(1,4 \times 0,5 \mathrm{~km})$, intrudido na Formação Água Clara, nas proximidades do Rio Piedade. Segundo Martini (op. cit.) é constituído pelos fácies monzogranito, fácies quartzo-monzonito, fácies granito-alaskítico e fácies granito. As variedades mais comuns são essencialmente quartzo-feldspáticas (leucocráticas), muito piritizadas.

Segundo Chiodi Filho et al. (1987) o Granito Barra do Santana possui maior abundância relativa em plagioclásios, quando comparado ao Granito Piedade. Os autores aventam a possibilidade de algumas características da intrusão serem atribuídas à contaminação do magma durante seu alojamento, com a assimilação parcial das rochas encaixantes ricas em cálcio.

\section{Granitos Serra do Carambeí e Joaquim Murtinho}

Foram primeiramente definidos durante os trabalhos da Comissão da Carta Geológica do Paraná (em Fuck et al., 1967), onde foram mapeados junto ao contato dos terrenos pré-cambrianos com o Grupo Castro. Foram considerados como granitos "alaskíticos", inscritos no Complexo Cunhaporanga.
Guimarães (2000) caracteriza essas intrusões como álcali-feldspato-granitos, reconhecendo deformação rúptil em suas bordas. O referido autor considera os aspectos petroquímicos de ambas intrusões como semelhantes aos granitos tipo-A (anorogênicos). Trabalhos da CPRM (1977) indicam a cristalização do Granito Serra do Carambeí com idade de $543 \pm 25 \mathrm{Ma}$ (Rb-Sr em rocha total).

\section{Granito Rio Abaixo}

O Granito Rio Abaixo se localiza a oeste no município de Rio Branco do Sul, intrusivo nas rochas da Formação Votuverava. Apresenta forma grosseiramente circular e uma área aproximadamente de $4,5 \mathrm{~km}^{2}$. É principalmente representado por biotita-granitos róseos, equigranulares a porfiríticos, de granulação média à grossa e isótropos. Segundo Martini (1982) este corpo apresenta contatos tectônicos e verticalizados, produzindo muitas vezes efeitos térmicos nas encaixantes. Santos e Felipe (1980) reconhecem neste corpo, três variedades petrográficas distintas: fácies granitos e quartzo-sienitos hipidiomórficos róseos; fácies granitos porfiríticos róseos e fácies cataclástica de cor cinza.

Dados petrográficos de Pinto Coelho e Siedlecki (1991) caracterizam quatro fácies magmáticas principais: granítica, álcali-feldspato granítica, álcali-feldspato sienítica e quartzo sienítica. Apesar das informações petrográficas, os autores destacam que as análises químicas caracterizam o granito como cálcio-alcalino, atribuindo este fato à influência da carbonatação, presente em grande parte da intrusão.

Cury (2003) descreve a predominância de monzogranitos com megacristais de microclínio em matriz de quartzo, plagioclásio, biotita, anfibólio, titanita, apatita, zircão e allanita. Os contatos do Granito Rio Abaixo são marcados por zonas de cisalhamento rúpteis ou por auréolas de metamorfismo termal nas encaixantes. Dados geocronológicos obtidos pelo autor através de análises U-Pb (zircão) forneceram a idade de $564 \pm 63 \mathrm{Ma}$.

\section{Sienito Rabo de Galo}

O Sienito Rabo de Galo (ou Capivara) constitui um corpo de aproximadamente $2,2 \mathrm{~km}^{2}$, localizado no município de Itaperussú, a norte do Granito do Cerne. Fiori (1990) e CPRM (1977) interpretam esta intrusão como uma apófise do Granito do Cerne. Durante os trabalhos de campo da disciplina de Mapeamento Geológico, realizado por alunos da UFPR em 2000, foram reconhecidas importantes diferenças em relação ao Granito do Cerne, notadamente quanto a sua composição sienítica.

Cury (2003) reconhece termos quartzo-sieníticos e sieníticos, sendo a rocha composta principalmente por 
microclínio, anfibólio e subordinadamente por clinopiroxênio hedenbergita, quartzo, plagioclásio, opacos, fluorita, titanita, apatita e zircão. Neste trabalho são reconhecidas duas fácies determinadas pela variação do anfibólio, ora cálcico, ora alcalino. O sienito é associado às intrusões dos granitos Cerne, Passa Três e Rio Abaixo, com idade U-Pb (zircão) de $553 \pm 9$ Ma, pouco mais jovem que os stocks graníticos.

\section{Monzonito Chacrinha}

O Monzonito Chacrinha foi primeiramente reconhecido na localidade de Freguesia dos Laras (trabalhos de mapeamento e integração da CPRM, 1977), como pequeno corpo granítico intrusivo, situado nas proximidades e a oeste do Granito Cerne. Trabalhos de campo realizados por alunos da disciplina de Mapeamento Geológico da UFPR, em relatórios internos de diversos anos, definem a presença de vários corpos intrusivos alinhados segundo NW-SE.

Cury (2003) descreve que a composição do mesmo varia de quartzo-monzonito a quartzo-monzodiorito, razão pela qual optou pela re-denominação de Monzonito Chacrinha. São rochas compostas por plagioclásio, k-feldspato, quartzo, hornblenda, clinopiroxênio, epidoto e clorita, com textura xenomórfica e feições micrográficas.

\section{Granito Cerne}

O Granito Cerne (Muratori, 1966), localiza-se a NW do município de Bateias (PR), cobrindo aproximadamente $45 \mathrm{~km}^{2}$. É constituído predominantemente por granitos leucocráticos, avermelhados, equigranulares, médios a grossos e composição sienogranítica a álcali-feldspato granítica. São rochas isótropas, por vezes com orientação mineral de fluxo magmático (Fuck et al., 1967; Silva et al., 1998). Texturas miloníticas ocorrem ao sul do Granito Cerne, impostas pela Falha do Cerne (Santos e Felipe, 1980).

Prazeres Filho (2000) sugere que no Granito Cerne predominam rochas shoshoníticas metaluminosas, compostas por microclínio, oligoclásio, quartzo, biotita e de traços de hornblenda, titanita, zircão, allanita, fluorita e minerais opacos.

O contato intrusivo com as unidades metavulcanossedimentares é evidenciado pela ocorrência de xenólitos de rochas metassedimentares e efeito de termo-metamorfismo sobre as rochas encaixantes (Fuck et al., 1967). Ao sul, este corpo é balizado pela Falha do Cerne (Fiori, 1990).

Fiori (1990) caracteriza uma falha de cavalgamento, contornando a antiforma do cerne, posicionando-a em sua maior parte, entre um corpo de quartzito e um pacote de filito. $\mathrm{O}$ autor denomina a estrutura de Falha de Ouro Fino.

Dados geoquímicos obtidos por Prazeres Filho (2000) caracterizam o Granito Cerne como pós-colisional. O autor apresenta idade de $569 \pm 31$ Ma (pelo método U-Pb em zircões) e interpreta como relativa à formação do maciço granítico. Cita também a idade K-Ar em biotita de $545 \pm$ $10 \mathrm{Ma}$, relativa ao resfriamento do granito. Siga Jr. (1995) determina idade Sm-Nd TDM de 2,0 Ga, relacionada à época de separação manto-crosta dos protólitos dessas rochas.

Cury (2003) descreve o predomínio de biotita-sienogranitos com megacristais de microclínio, geralmente isótropos ou com foliação de fluxo magmático. Com menor freqüência, ocorre termos monzograníticos e quartzosieníticos. Nas regiões de borda ocorrem faixas métricas de termos deformados como gnaisses e, com menor freqüência, milonitos. O autor associa o Granito do Cerne ao mesmo evento de intrusão dos granitos Passa Três e Rio Abaixo e classifica essas rochas como granitos tipo-A, com ressalvas quanto aos altos teores de $\mathrm{Ba}$, Sr e Zr. Apresenta idade U-Pb zircão (TIMS) de $563 \pm 34$ Ma, assumida como cristalização do Granito do Cerne.

\section{Granito Passa Três}

O Granito Passa Três (Piekarz, 1981) ocorre nas proximidades do município de Campo Largo, abrangendo uma área de aproximadamente $5 \mathrm{~km}^{2}$. Picanço (2000) e Piekarz (1981, 1992) descrevem que esse maciço é constituído por sienogranitos, distribuídos em dois domínios:

1. sienogranito-melagranito róseo, equigranular, médio a grosso;

2. sienogranito-leucogranito róseo, equigranular e médio.

Ocorrem ainda veios de aplitos, pegmatóides e microgranitos e de quartzo ricos em sulfetos, representativos de fases tardias da formação do Granito Passa Três. Os veios de quartzo são mineralizados, constituindo o depósito aurífero mais importante da região (Soares e Góis, 1987; Piekarz, 1981, 1992; Picanço, 2000). Os contatos desse corpo com as unidades metavulcanossedimentares adjacentes são por zonas de cisalhamento, como a da Falha do Cerne, no contato norte.

Picanço (2000) obteve uma isócrona mineral Sm-Nd com idade de $616 \pm 36 \mathrm{Ma}$, considerada com ressalvas devido à intensa alteração hidrotermal do maciço e por não se tratar de isócrona de boa qualidade, como considerado pelo próprio autor. $\mathrm{O}$ autor admite que a mineralização aurífera tem idade entre 510 e $527 \mathrm{Ma}$, como sugerem os dados isotópicos K-Ar em sericita (zonas de falha, $528 \pm 10 \mathrm{Ma}$ ), Rb-Sr da encaixante mineralizada (526 $\pm 23 \mathrm{Ma}$ ) e de lixiviados de pirita $(510 \pm 13 \mathrm{Ma})$.

Estudos geoquímicos de Cury (2003) mostram que os litotipos deste corpo apresentam semelhanças no conteúdo de ETR e elementos traço com os granitos Cerne e Rio Abaixo. Os dados isotópicos de Sr e Nd também são seme- 
lhantes $\left(\varepsilon_{\mathrm{Sr}}=70\right.$ a $120 ; \varepsilon_{\mathrm{Nd}}=-11$ a -15$)$, com idades Sm-Nd TDM muito próximas ( $2 \mathrm{Ga}$ a 2,2 Ga), sugerindo mesma fonte. $\mathrm{O}$ autor associa esses maciços a um único magmatismo e considera as características petrológicas e geoquímicas como semelhantes aos granitos tipo-A. Soares e Góis (1987) e Picanço (2000) sugerem que essas rochas se formaram a partir da mistura de fontes mantélicas e crustais.

\section{CARACTERISTICAS GEOLÓGICO-ESTRUTURAIS}

A comparação entre os padrões estruturais dos maciços graníticos, rochas encaixantes e zonas de cisalhamento adjacentes é a principal ferramenta para o estudo das condições de instalação desses corpos. Os granitos Cerne, Passa Três e Rio Abaixo (Figura 2) são isótropos ou com foliação de fluxo magmático na maior extensão (Figura 3). Em locais restritos próximos às zonas de contato, ocorrem granitognaisses expressos por termos foliados e bandados, com deformação dúctil-rúptil (Figura 4) e superfícies de alto ângulo de mergulho.

Há consenso entre os autores (Ebert, 1971; Fiori et al., 1987; Fiori, 1985a, 1990, 1992; Soares e Reis Neto, 1987; Hasui et al., 1984; Hasui, 1986; Salamuni et al., 1992; Fassbinder, 1996; Daitx, 1996; Kaulfuss, 2000; Cury et al., 2002) de que os terrenos do Pré-cambriano paranaense foram afetados por pelo menos duas fases de deformação, a primeira associada à tectônica de cavalgamentos e a segunda associada à tectônica de transcorrências.

A foliação de baixo ângulo S1 é de caráter regional nesses terrenos, sendo caracterizada por sericita, muscovita e biotita paralelas ou subparalelas ao bandamento composicional. Essa superfície é cortada por uma foliação cisalhante Sc (ou S2), também de baixo ângulo, heterogeneamente desenvolvida, que tendem a se concentrar nas proximidades das falhas de cavalgamento.

As foliações de baixo a médio ângulo (S1e S2) de rochas das formações Betara e Votuverava, adjacentes aos maciços graníticos Cerne, Passa Três, Rio Abaixo e Sienito Rabo de Galo, possuem comportamento semelhante e são aqui apresentadas conjuntamente. O estereograma da Figura 5 mostra concentrações de pólos nos quadrantes SE e NW, com atitudes e máximas em N40E/39NW e N30E/58SE, com guirlanda sugestiva de dobras abertas e assimétricas, com eixo (e) em N32/10 .

Próximo às zonas de cisalhamento (Cerne, Morro Agudo e Lancinha) as foliações de baixo a médio ângulo (S1 e S2) estão crenuladas ou transpostas pela foliação S3, de alto ângulo. Trata-se de foliação de cisalhamento caracterizada pela orientação/re-orientação e estiramento dos minerais, por vezes em ribbons (Figura 4), feldspatos rotacionados, sigmóides, S-Sc, com lineações subhorizontais e superfí- cies com mergulhos tanto para SE quanto para NW. Os máximos situam-se próximos de N35E, subvertical (Figura 6).

A foliação dos stocks graníticos é de alto ângulo, com mergulhos para os quadrantes SE (subvertical) e NW, (subvertical a $55^{\circ}$ ), com padrão semelhante ao obtido para as seqüências metassedimentares adjacentes aos maciços (Figuras 6 e 7). Esta foliação ocorre nas regiões de borda dos maciços e é caracterizada pelo bandamento composicional, que pode evoluir para termos com texturas protomiloníticas, miloníticas e ultramiloníticas em faixas restritas.

A semelhança entre a direção do eixo (e) das dobras e a direção das superfícies de alto ângulo (S3) sugere trataremse de estruturas geradas sob mesmo regime de esforços, em fase deformacional posterior a geração das foliações de baixo a médio ângulo (S1 e S2). Assim, as sinformas e antiformas parecem se associar aos planos de cisalhamento de alto ângulo, tendo se desenvolvido durante o evento transcorrente/transpressivo. As dobras são abertas, com caimento do eixo variando de subhorizontais a $20^{\circ}$, ora para NE, ora para SW. As superfícies de alto ângulo possuem direções NE a NNE e mergulhos que variam de subverticais até $70^{\circ}$ ora para SW, ora para NE, não ocorrendo homogeneamente por todo pacote de rochas metassedimentares, sendo mais expressivas nas proximidades das zonas de cisalhamento Lancinha, Morro Agudo e Falha do Cerne.

As zonas de cisalhamento Morro Agudo e Lancinha são as estruturas de maior expressão regional e balizam a área de ocorrência dos granitos do Cerne, Passa Três, Rio Abaixo e Sienito Capivara. Também a Falha do Cerne possui expressão neste contexto e é considerada como componente sintética da Zona de Cisalhamento Lancinha. Todas são transcorrentes, aparentemente em nível estrutural médio à superior. Fiori (1990), Fassbinder (1996), dentre outros autores, interpretam essas zonas de cisalhamento como de cinemática dextral. Indicadores cinemáticos, tais como porfiroclastos de feldspato rotacionados e foliações S-C caracterizam movimentação predominantemente dextral nas adjacências dos maciços graníticos do Cerne, Passa Três e Rio Abaixo.

\section{ANÁLISES ${ }^{40} \mathrm{Ar}-{ }^{39} \mathrm{Ar}$}

Para obtenção dos minerais a serem analisados por este método, a amostra deve ser reduzida à fração entre 60 e 100 mesh, com grãos livres de agregados. Sua concentração é realizada com auxílio de separador magnético Frantz, líquidos densos, a exemplo do bromofórmio $\left(\mathrm{d}=2,85 \mathrm{~g} / \mathrm{cm}^{3}\right)$ e catação manual em lupa. O processo de preparação da amostra envolve a irradiação em reator nuclear dos minerais selecionados ( $\sim 30$ cristais), produzindo artificialmente ${ }^{39} \mathrm{Ar}$ a partir do ${ }^{39} \mathrm{~K}$. Esse procedimento foi realizado no IPEN/USP. Após essa etapa, a extração de Ar é realizada por 


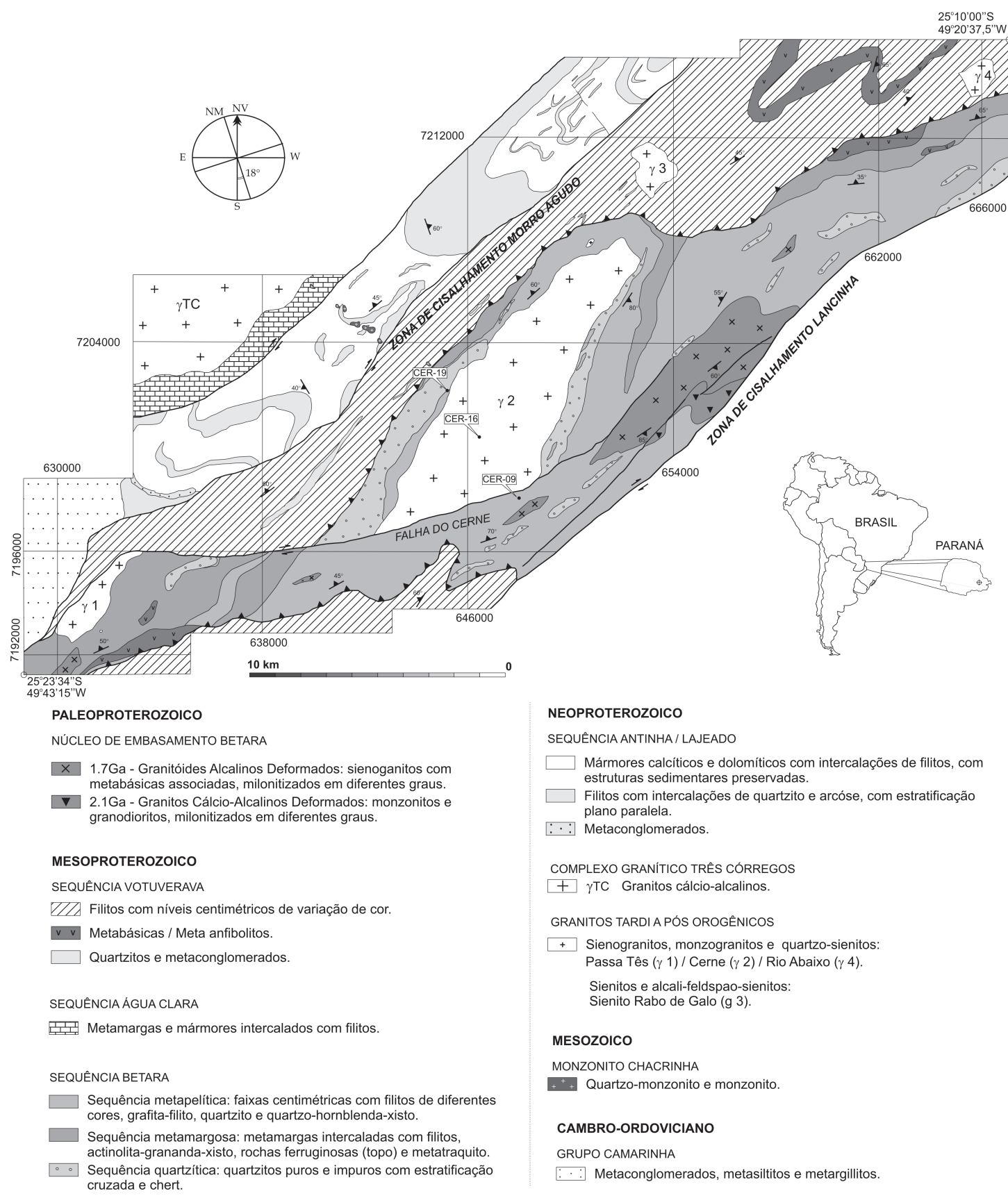

Figura 2. Mapa geológico dos granitos. Mesozóico - Intrusivas Básicas: (Mch) Monzonito Chacrinha. Cambro-ordoviciano - Formação Camarinha: (COCa) metargilitos, metasiltitos, metarenitos e metaconglomerados polimíticos. Neoproterozóico - (PCc) Granito do Cerne; (PCpt) Granito Passa Três; (PCra) Granito Rio Abaixo; (Pcca) Sienito Capivara; (PCTc) Complexo Granítico Três Córregos. Seqüência Antinha/Grupo Lajeado: (L1) mármores com intercalções de filitos, metarritmitos; (L2) filitos; (L3) mármores e margas com intercalações metapelíticas e metapsamíticas. Mesoproterozóico Formação Votuverava: (PCV1) metarritmitos, filitos e metaconglomerados; (PCV2) filitos, metarritmitos, mármores e conglomerados; (PCV3) metarritmitos, mármores, cálcio-silicáticas e metabásicas intercaladas. Formação Água Clara: (PCAc1) mármores e margas com intercalações de filitos, xistos e quartzitos; (PCAc2) metapelitos, metapsamitos, mármores e metavulcânicas. Formação Capirú: (PCC1) mármores, filito e quartzitos; (PCC2) filitos e quartzitos com mármores intercalados; (PCC3) filitos e quartzitos. Paleoproterozóico - Núcleo Betara: (PCB1) granitóides alcalinos deformados; (PCB2) xistos e quartzitos; (PCB3) filitos e margas, cálcio-silicáticas e metabasitos. 

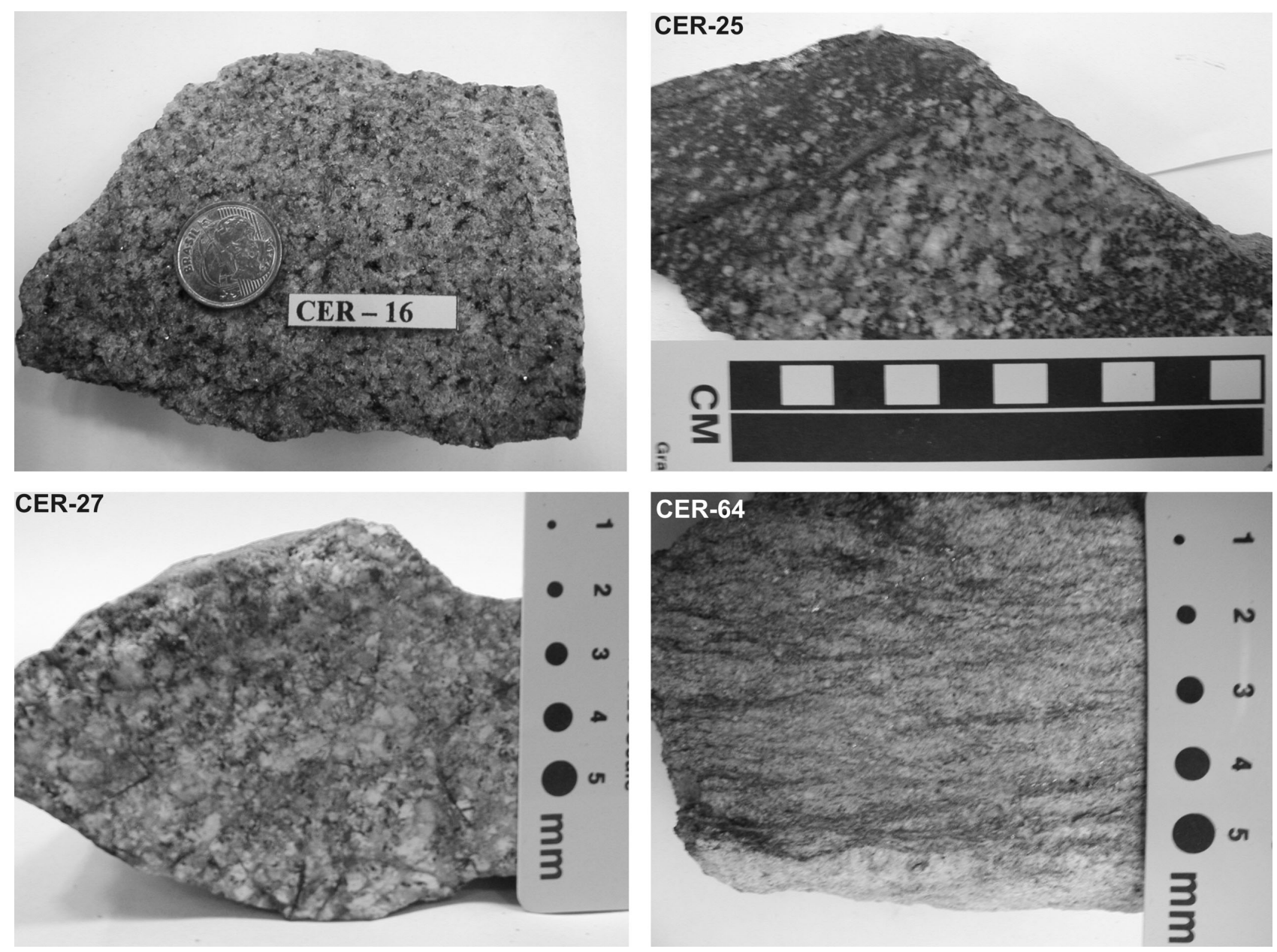

Figura 3. Fotos dos litotipos graníticos: fácies isótropo (CER-16), fácies com bandamento cumulático (CER-25), com textura cataclástica (CER-27) e textura milonítica (CER-64) .

incidência do feixe de raio laser sobre o cristal. São analisados normalmente três cristais por amostra, para obter-se maior confiabilidade dos dados, conforme rotina do laboratório Ar-Ar do CPGeo - IGc/USP. Os dados são apresentados em diagramas Idade (Ma) vs. ${ }^{39} \mathrm{Ar}(\%)$, um para cada cristal analisado. Os três resultados da amostra são integrados em diagrama de freqüência de idades (ideograma). Mais informações sobre o método podem ser encontradas em Vasconcelos et al. (2002), Renne (2000), Kawashita e Torquato (1993) e Mc Dougal e Harrison (1988).

\section{Resultados obtidos}

Análises Ar-Ar foram realizadas em biotitas de amostra de sienogranito do Granito do Cerne (CER-16) e em duas muscovitas das rochas encaixantes próximas ao contato desse corpo. As duas amostras de muscovita das rochas encaixantes, provêm de muscovita-quartzo-xistos da Formação Betara próximos à zona de contato com o Granito do Cerne, localizadas na porção sul (CER-09) e oeste (CER-19).

Na amostra CER-16, os três grãos analisados definem patamares com idades entre 555 e $560 \mathrm{Ma}$ (Figura 8). Quando plotados conjuntamente em ideograma (Figura 8), indicam idade de $557 \pm 2 \mathrm{Ma}$, bastante próxima dos valores obtidos nos interceptos inferiores dos diagramas concórdia, por análises U-Pb (TIMS) em zircão (563 + 34 Ma). A idade obtida é interpretada como resfriamento do Granito do Cerne, em isoterma entre $250-300^{\circ} \mathrm{C}$.

Na amostra CER-09, as muscovitas analisadas não definiram platôs e sugerem perdas parciais de argônio, com idade mínima próxima a 1200 Ma (Figura 9). Tal valor provavelmente não apresenta significado geológico, mas denota que a cristalização da muscovita no xisto é mais antiga que a 

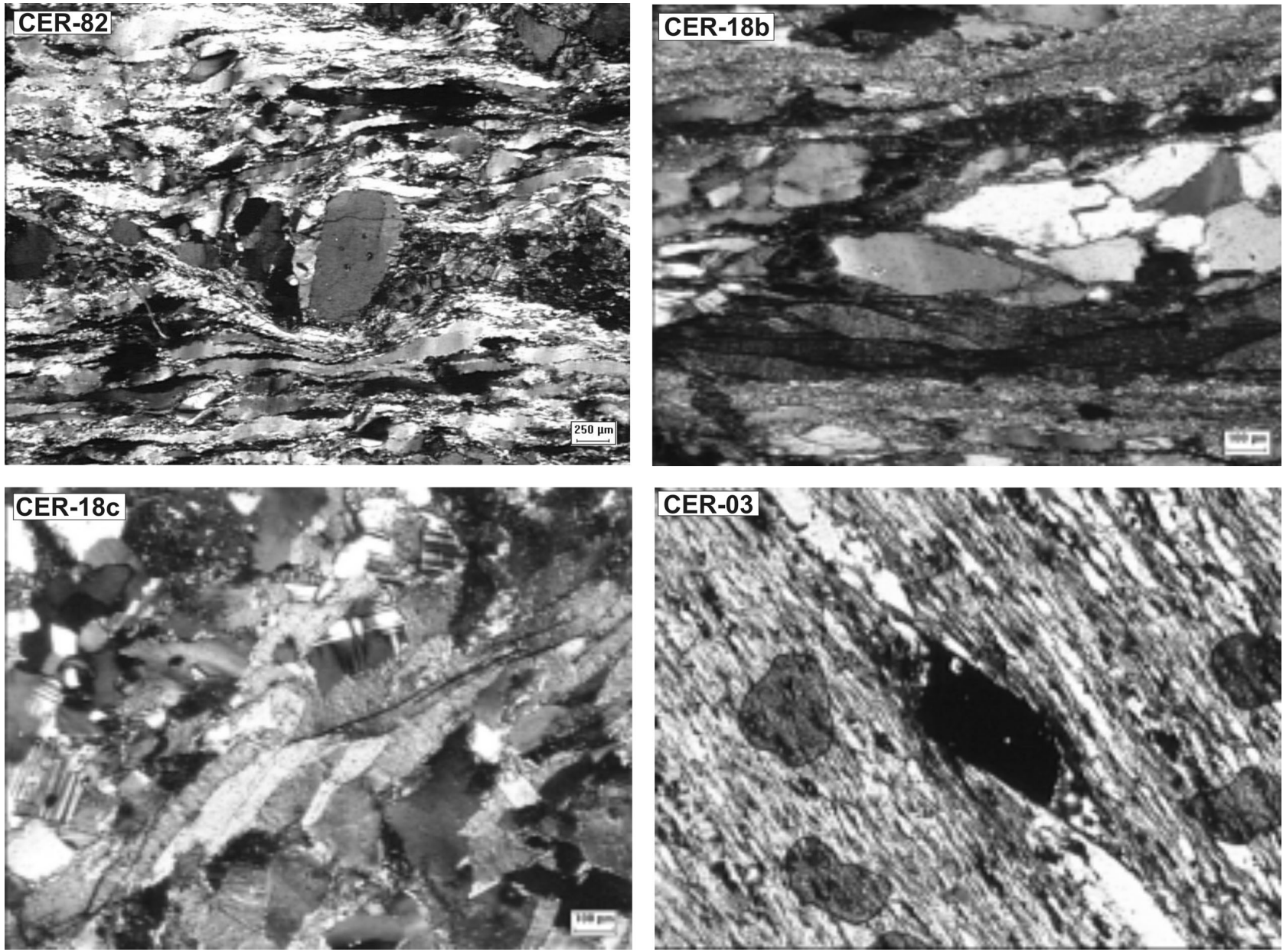

Figura 4. Fotomicrografias das microtexturas dos granito-gnaisses, com cristais de K-feldspato rotacionados (CER-82), bandamento (CER-18B), mica fish (CER-18C) e sigmóides (CER-03).

colocação do Granito do Cerne. Neste contexto, a perda de argônio deve estar relacionada à instalação do maciço granítico e/ou ao desenvolvimento das zonas de cisalhamento adjacentes, durante o Neoproterozóico.

Os dados Ar-Ar de muscovitas das rochas metassedimentares da Formação Betara, próximas ao contato oeste do Granito do Cerne (amostra CER-19), definem idades relativamente mais jovens, em torno de $840 \pm 30 \mathrm{Ma}$ (Figura 10). Os steps mostram comportamento irregular e não definem platôs, o que dificulta a interpretação da idade mínima, sem significado geológico. Porém, a exemplo da amostra CER-09, os valores obtidos são mais antigos que a idade de resfriamento do Granito do Cerne.

As idades obtidas nas muscovitas são sistematicamente mais antigas que a obtida no Granito do Cerne e podem representar idades mínimas de um evento metamórfico Préneoproterozóico (1200 Ma ou mais antigo), observado no âmbito da Formação Betara. Não se pode descartar também a possibilidade de serem grãos de muscovita detrítica, com herança isotópica da área fonte, com perdas parciais de Ar relacionadas a eventos posteriores. Outro fator a ser considerado, embora pouco provável, é o excesso de Ar provocado pela influência de fluídos hidrotermais, resultando assim, idade mais antiga sem significado geológico.

Análises adicionais em muscovita e sericita muito fina desenvolvidas em meio à foliação de alto ângulo são relevantes para uma melhor compreensão sobre os eventos relacionados a zonas de cisalhamento e a colocação dos stocks graníticos tardi-tectônicos. Também está sendo investigado o desenvolvimento da muscovita no âmbito da Formação Betara, principalmente nas proximidades das zonas de cisalhamento de baixo ângulo, para verificar a presença de um evento metamórfico mais antigo do que o Ciclo Brasiliano, inédito no Domínio Apiaí. 
Figura 5. Foliações S1/S2 das rochas metassedimentares das formações Votuverava e Betara localizadas nas vizinhanças das intrusões dos granitos Cerne, Passa Três e Rio Abaixo.

Figura 6. Foliação S3 das rochas metassedimentares das formações Votuverava e Betara localizadas nas vizinhanças das intrusões dos granitos Cerne, Passa Três e Rio Abaixo. A S3 é bem caracterizada nas proximidades com os limites das intrusões.

Figura 7. Foliação S3 dos granitos Cerne, Passa Três e Rio Abaixo.

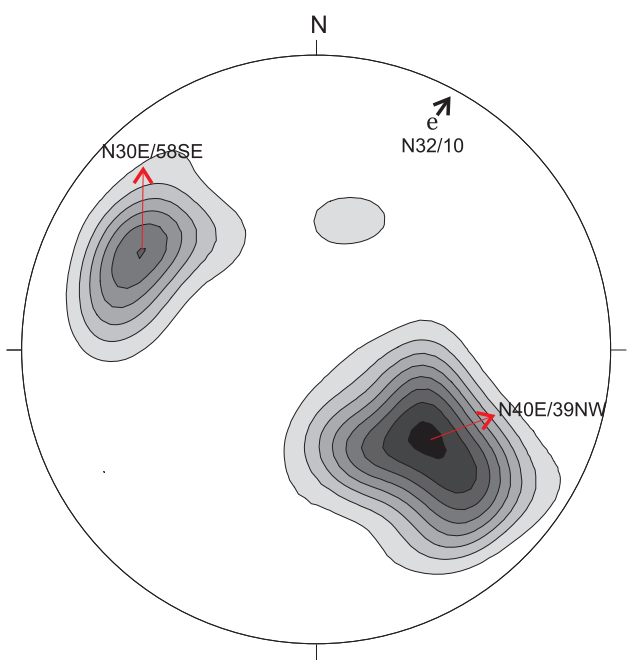

Diagrama de Equiárea $(n=110)$

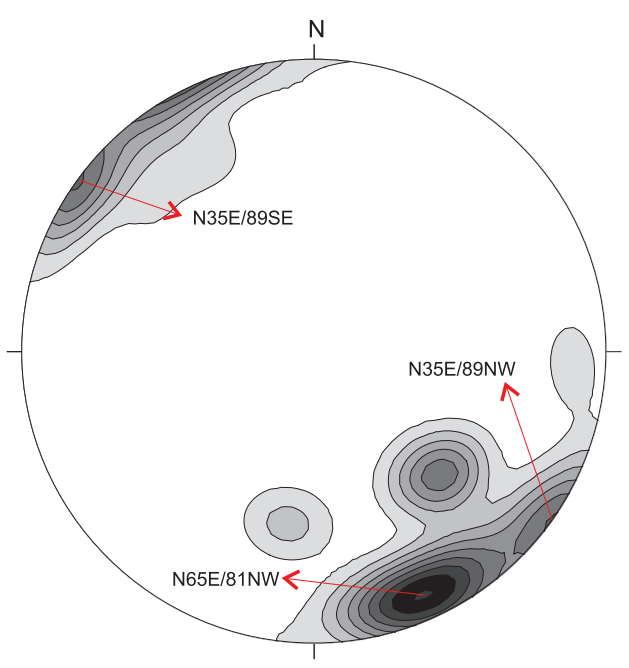

Diagrama de Equiárea $(n=56)$

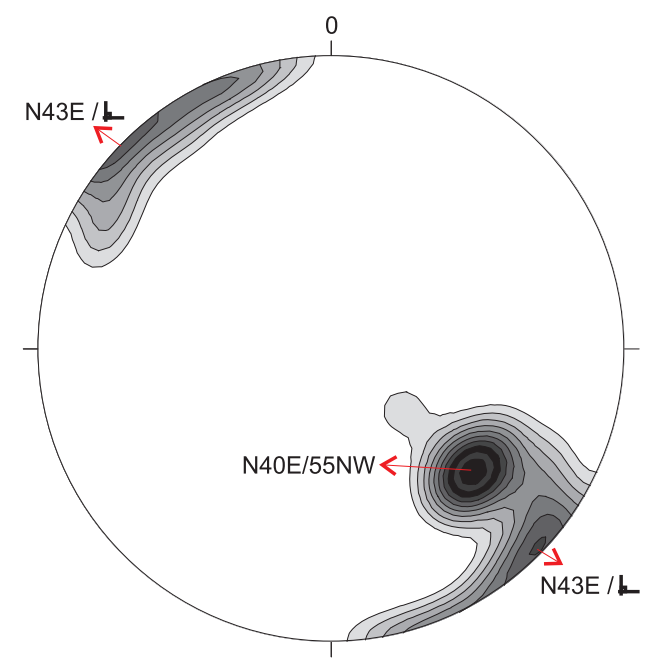

Diagrama de Equiárea $(n=19)$ 

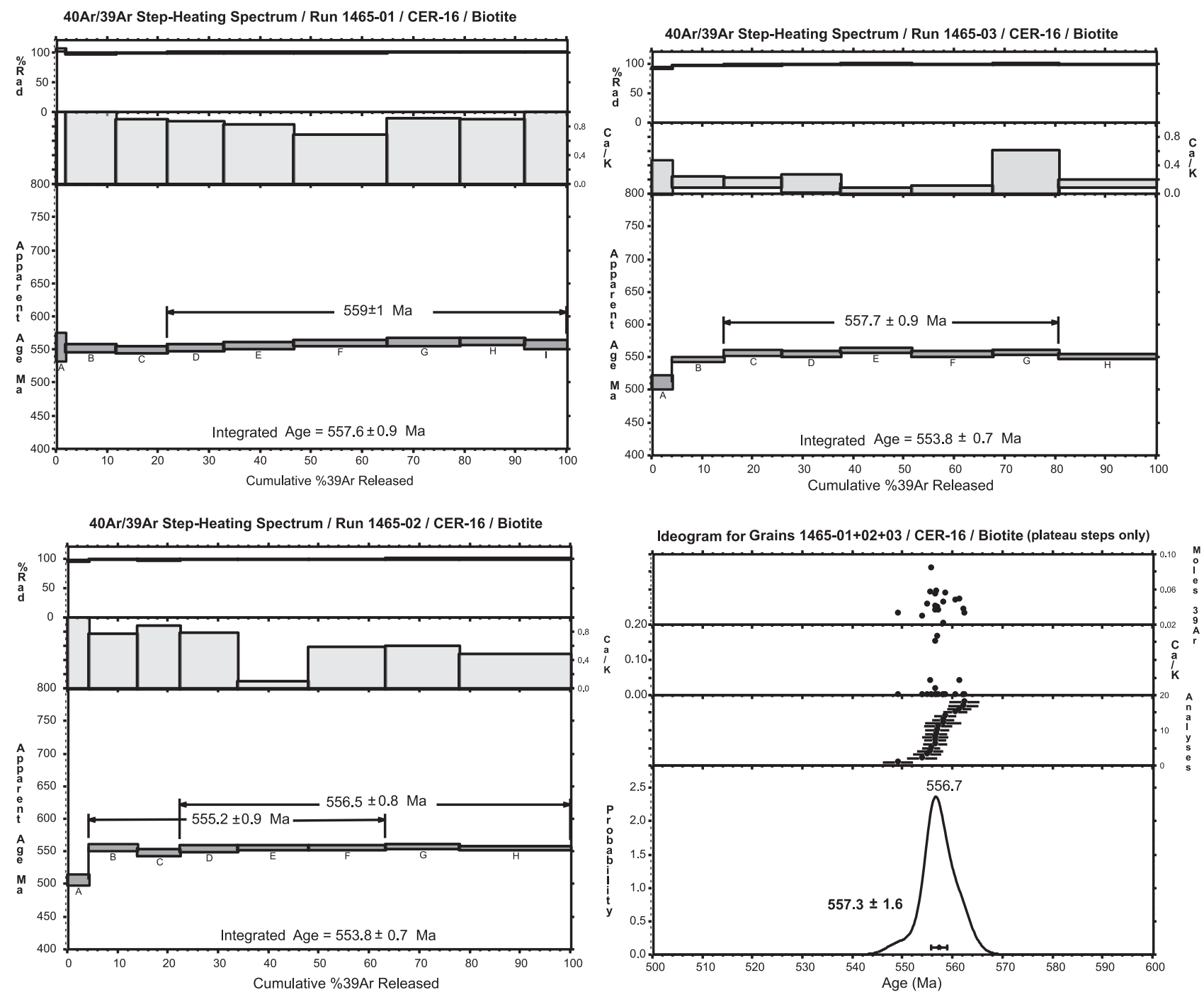

Figura 8. Diagramas Ar-Ar dos três cristais de biotita do Granito do Cerne, com as idades integradas (amostra CER-16). 

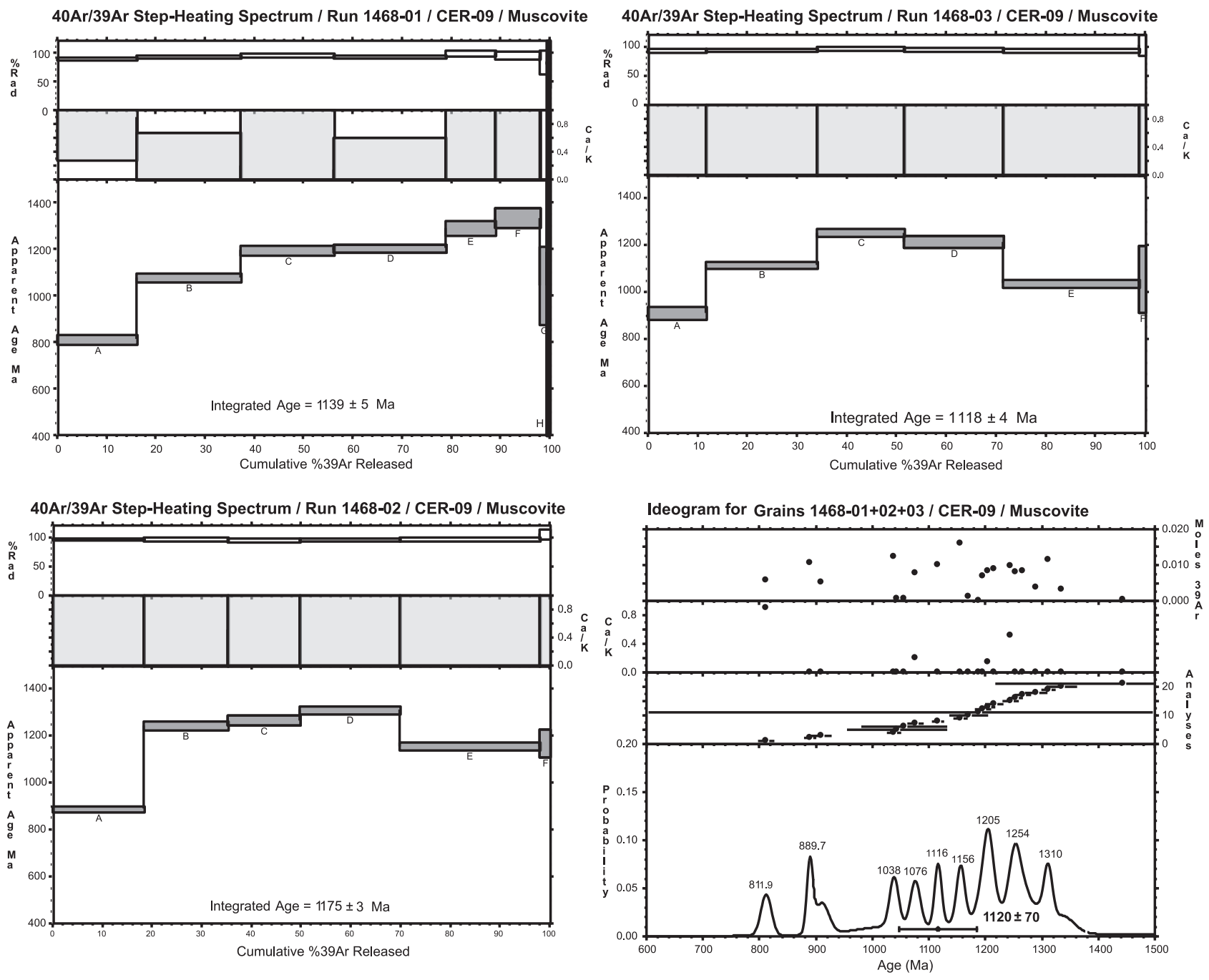

Figura 9. Diagramas Ar-Ar dos três cristais de muscovita da Formação Betara e idades integradas (amostra CER-09). 

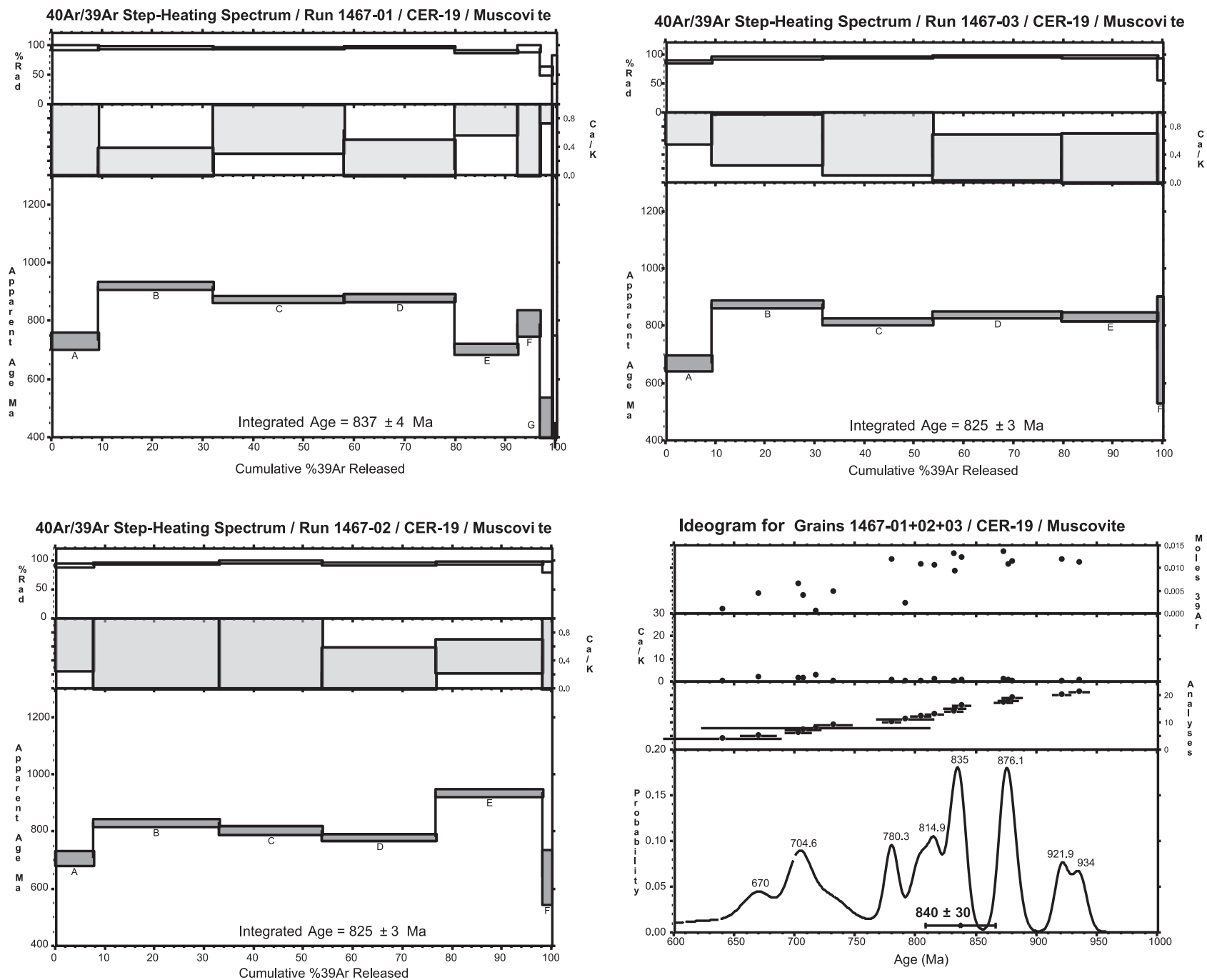

Figura 10. Diagramas Ar-Ar dos três cristais de muscovita da Formação Betara e idades integradas (amostra CER-19). 


\section{CONSIDERAÇÕES FINAIS}

Os granitos do Cerne, Passa Três e Rio Abaixo se encontram posicionados em zona transpressiva entre as zonas de cisalhamento Lancinha e Morro Agudo, onde a intrusão e colocação desses stocks ocorreu associada aos sistemas de transcorrências e ao desenvolvimento das grandes antiformas e sinformas. Representam, portanto, um magmatismo tardi-orogênico em relação ao regime de transpressão (sensu Robin e Cruden, 1994) e ao arco magmático Três Córregos-Cunhaporanga, no âmbito do Domínio Apiaí.

Análises Ar-Ar em biotita do Granito do Cerne indicam uma idade integrada de $557 \pm 2 \mathrm{Ma}$, relativamente próxima da idade de cristalização do zircão (563 $\pm 34 \mathrm{Ma})$, o que sugere período de tempo relativamente curto entre a formação desse corpo e seu posicionamento a temperaturas inferiores a $250-300^{\circ} \mathrm{C}$. Este período, do Proterozóico Superior/ Cambriano, representa importante marco na região, associado aos ajustes finais relacionados à aglutinação do Supercontinente Gondwana.

As análises Ar-Ar em muscovita de xistos da Formação Betara, adjacentes ao Granito do Cerne, forneceram valores da ordem de $1120 \pm 70 \mathrm{Ma}$, no contato sul, e $840 \pm 30 \mathrm{Ma}$, no contato oeste. Embora imprecisas, estas idades se revestem de importância pois revelam que a colocação do Granito do Cerne não provocou aquecimento superior a $300^{\circ} \mathrm{C}$ em rochas próximas ao seu contato. Estas idades são mais antigas que o pico metamórfico regional do Neoproterozóico ( $\sim 00 \mathrm{Ma}$ ), evento marcante e reconhecido em todo Pré-cambriano paranaense, o que permite concluir que idades mais antigas em muscovita não foram totalmente apagadas durante o metamorfismo regional e a intrusão do Granito do Cerne.

\section{AGRADECIMENTOS}

Os autores agradecem ao Programa de Pós Graduação em Geoquímica e Geotectônica e ao Centro de Pesquisas Geocronológicas (CPGeo) do Instituto de Geociências USP, em especial ao Laboratório Ar-Ar, coordenado na época de realização das análises aqui apresentadas pelo Prof. Dr. Umberto Giuseppe Cordani. Também agradecem aos relatores da revista Geologia USP pela contribuição significativa na qualidade do texto.

\section{REFERÊNCIAS BIBLIOGRÁFICAS}

ALGARTE, J. P.; KAEFER, L. Q. Relatório Geológico Preliminar da Folha de Itararé - SP. Brasília: Convênio DNPM/CPRM, v. 1, 1972. 180 p.

BASEI, M. A. S.; SIGA JUNIOR, O.; MACHIAVELLI, A.;
MANCINI, F. Evolução tectônica dos terrenos entre os Cinturões Ribeira e Dom Feliciano (PR - SC). Revista Brasileira de Geociências, v. 22, n. 2, p. 216-221, 1992.

BASEI, M. A. S.; SIGA JUNIOR, O.; REIS NETO, J. M.; HARARA, O. M. M.; PASSARELLI, C. R.; MACHIAVELLI, A. Geochronological map of the Precambrian terrains of Paraná and Santa Catarina states, southern Brazil: Tectonic Implications. In: SOUTH-AMERICAN SYMPOSIUM ON ISOTOPE GEOLOGY, 1., 1997. Campos do Jordão. Extended Abstracts... Campos do Jordão: SSAGI, 1997, p. 44-46.

BASEI, M.A. S.; SIGAJUNIOR, O; KAULFUSS, G. A.; CORDEIRO, H.; NUTMAN, A.; SATO, K.; CURY, L. F.; PRAZERES FILHO, H. J.; PASSARELLI, C. R.; HARARA, O. M. M.; REIS NETO, J. M. Magmatismo básico mesoproterozóico no Vale do Ribeira: implicações na idade de deposição das seqüências metavulcanossedimentares Perau e Votuverava, Estado do Paraná, Brasil. In: SOUTH-AMERICAN SYMPOSIUM ON ISOTOPE GEOLOGY, 4., 2003. Salvador. Extended Abstracts... Salvador: SSAGI, 2003, p. 501-504.

CAMPANHA, G. A. C. Tectônica Proterozóica no alto e Médio Vale do Ribeira, Estados de São Paulo e Paraná. 1991. 296 f. Tese (Doutoramento) - Instituto de Geociências, Universidade de São Paulo, São Paulo.1991.

CAMPANHA, G. A. C.; SADOWSKI, G. R. Tectonics of southern portion of the Ribeira Belt (Apiaí Domain). Precambrian Research, n. 98, p. 31-51, 1999.

CHIODIFILHO, C.; MORETZSON, J. S.; SANTOS, J. F.; SOARES, P. C. Aspectos geológicos e metalogenéticos dos granitos Morro Grande, Piedade e Varginha - Vale do Ribeira Paraná. In: SIMPÓSIO SUL-BRASILEIRODE GEOLOGIA, 3., 1987. Curitiba. Anais... Curitiba: SBG, 1987, v. 2, p. 515-542.

CHIODI FILHO, C.; SANTOS, J. F.; SOARES, P. C.; MORETZSHON, J. S. 1989. Estudo ETR para caracterização e avaliação metalogenética de granitóides no escudo paranaense. In: CONGRESSO BRASILEIRO DE GEOQUIMICA, 2., 1989. Rio de Janeiro. Anais... Rio de Janeiro: SBG, 1989, v. 2, p. 487-498.

COMISSÃO DA CARTA GEOLÓGICA DO PARANÁ CODEPAR. Geologia do Pré-Devoniano e intrusivas subseqüentes da porção oriental do Estado do Paraná. Boletim Paranaense de Geociências, v. 23-25, p. 1-347, 1967.

COMPANHIADE PESQUISA DE RECURSOS MINERAIS - CPRM. Projeto Leste do Paraná - mapas geológicos das folhas Apiaí, Barra do Rio Pitangui, Campo Largo, Cêrro 
Azul, Curitiba, Guaraqueçaba, Palmeira, Piraí do Sul, Ponta Grossa. Curitiba: Convênio CPRM/DNPM/UFPR/ BADEP, 1977. 9 mapas, color., Escala: 1:100.000.

CURY, L. F.; KAULFUSS, G.A.; SIGAJUNIOR, O.; BASEI, M. A. S.,HARARA, O. M. M.; SATO, K. Idades U-Pb (zircões) de 1.75 Ga em granitóides alcalinos deformados dos núcleos Betara e Tigre: Evidências de regimes extensionais do Estateriano na Faixa Apiaí. Geologia USP. Série Científica, v. 2, p. 95-108, 2002.

CURY, L. F. Geocronologia e Litogeoquímica dos Stocks Graníticos da Porção Sudeste da Faixa Apiaí, Estado do Paraná. 2003. 125 f. Dissertação (Mestrado) - Instituto de Geociências, Universidade de São Paulo, São Paulo, 2003.

DAITX, E. C. Origem e evolução dos depósitos sulfetados tipo Perau (Pb-Zn-Ag), com base nas jazidas Canoas e Perau (Vale do Ribeira - PR). 1996. Tese (Doutoramento) Instituto de Geociências. UNESP, Rio Claro, 1996.

EBERT, H. 1971. Observações sobre a litologia e subdivisão do “Grupo Setuva” no Estado do Paraná: com sugestões à tectônica geral do "Geossinclíneo Açungui”. In: CONGRESSO BRASILEIRO DE GEOLOGIA, 25., 1971. São Paulo. Anais... São Paulo: SBG, 1971. v. 1, p. 131-146.

EBERT, H. D.; HASUI, Y.; QUADE, H. Aspectos da evolução estrutural do cinturão móvel costeiro da mina do Perau, Vale do Ribeira-PR. In: CONGRESSO BRASILEIRO DE GEOLOGIA, 35., 1988. Belém. Anais... Belém: SBG 1988, p. 2318-2331.

FASSBINDER, E. A unidade Água Clara no contexto do Grupo Açungui: um modelo transpressivo de colisão oblíqua no Neoproterozóico paranaense. 1996. 207 f. Tese (Doutorado) - Instituto de Geociências, Universidade de São Paulo, São Paulo, 1996.

FIORI, A. P. Aplicação do modelo de cisalhamento simples na análise da deformação de alguns granitos paranaenses. Boletim Paranaense de Geociências, n. 36, p. 31-40, 1985.

FIORI, A. P.; FASSBINDER, E.; GOIS, J. R.; FUMAGALLI, C. E. 1987. Compartimentação tectônica do Grupo Açungui a norte de Curitiba. In: SIMPÓSIO SUL-BRASILEIRO DE GEOLOGIA, 3., 1987. Curitiba-PR. Anais... Curitiba: SBG, 1987, v. 1, p. 183-196.

FIORI, A. P. Tectônica e estratigrafia do Grupo Açungui a norte de Curitiba. 1990, 261 f. Tese (Livre Docência) Instituto de Geociências , Universidade de São Paulo, São Paulo, 1990.
FIORI, A. P. Evolução geológica da Bacia Açungui. Boletim Paranaense de Geociências, v. 42, p. 7-27, 1992.

FIORI, A. P.; GASPAR, L. A. Considerações sobre a estratigrafia do Grupo Açungui (Proterozóico Superior), Paraná, sul do Brasil. Boletim IG-USP: Série Científica, v. 24, p. 1-19, 1993.

FUCK, R.A.; MARINI, O. J.; TREIN, E. Contribuição ao estudo ao estudo das rochas graníticas do Estado do Paraná. Boletim Paranaense de Geociências. v. 23-25, p. 183-221, 1967.

GIMENEZ FILHO, A. Evolução do Complexo Granítico Três Córregos a noroeste de Apiaí- SP. 1993. 118 f. Dissertação (Mestrado) - Instituto de Geociências, Universidade de São Paulo,1993.

GUIMARÃES, G. B. As rochas granitóides do Complexo Granítico Cunhaporanga, Paraná: Aspectos geológicos, geofísicos, geoquímicos e mineralógicos. 2000, 230 f. Tese (Doutorado) - Instituto de Geociências, Universidade de São Paulo, São Paulo, 2000.

HACKSPACHER, P. C.; DANTAS, E. L.; VAN SCHUMUS, W. R.; FETTER, A. 1997. Terrenos exóticos na Faixa Ribeira, sim ou não? In: SIMPÓSIO REGIONAL DE GEOLOGIA, 5., 1997. São Paulo. Atas... São Paulo: SBG, 1997, v. 1, p. 69-71.

HACKSPACHER, P. C.; DANTAS, E. L.; SPOLADORE, A.; FETTER, A. H.; OLIVEIRA, M. A. F. Central Ribeira Belt, southeastern Brazil: new geochronological and geochemical constrains from the São Roque - Açungui Groups. Revista Brasileira de Geociências, v. 30, n. 1, p. 110-114, 2000.

HASUI, Y.; EBERT, H. D.; QUADE, H. 1984. Aspectos geológicos da megantiforme da Serra do Cadeado (PR). In: CONGRESSO BRASILEIRO DE GEOLOGIA, 33., 1984. Rio de Janeiro. Anais... Rio de Janeiro: SBG, 1984, v. 5, p. 2380-2393.

HASUI, Y. Novo modelo geológico do Vale do Ribeira. São Paulo, Instituto de Pesquisas Tecnológicas - IPT. 1986. 742 p. (Relatório $n^{0} .23$ ).

HASUI, Y.; CARNEIRO, C. D. R.; COIMBRA, A. M. The Ribeira Folded Belt. Revista Brasileira de Geociências, v. 5, p. 257-266, 1975.

JICA/MMAJ. Report on the Geological Survey of Anta Gorda: Phase II. Convênio DNPM / Metal Mining Agency of Japan, 1982. 
KAULFUSS, G. A. Geocronologia dos Núcleos de Embasamento Setuva, Betara e Tigre, Norte de Curitiba- PR. 2001. 115 f. Dissertação (Mestrado) - Instituto de Geociências, Universidade de São Paulo, São Paulo, 2001.

KAWASHITA, K.; TORQUATO, J. R. Geocronologia Nuclear - O Método 40Ar/39Ar. Revista IGc-USP: Série Científica, v. 6, p. 129-156, 1993.

LANDIN, P.M. B.; GOMES, C. B.;ARRUDA, J. R.; FÚLFARO, V. J. Análise de agrupamentos aplicada ao estudo geoquímico do Granito Itaoca. In: CONGRESSO BRASILEIRO DE GEOLOGIA, 27., 1975. Porto Alegre. Anais... Porto Alegre: SBG, 1975, p. 269-270.

MARTINI, S. L. Reconhecimento dos Granitos Taici e Rio Abaixo. Curitiba : MINEROPAR, 1982.17p. (Relatório).

MCDOUGALL, I.; HARRISON, T. M. Geochronology and thermochronology by 40Ar/39Ar method. Oxford: University Press, 1988. 212 p.

MELCHER, G. C.; GOMES, C. B.; CORDANI, U. G.; BETTENCOURT, J. S.; DAMACENO, E. C.; GIRARDI, V.A. V.; MELFI, A. J. Geologia e petrografia das rochas metamórficas e graníticas associadas do Vale do Ribeira de Iguape, SP e PR. Revista Brasileira de Geociências, v. 3, n. 2, p. 97-123, 1973.

MELLO, I. S. C.; BETTENCOURT, J. S. 1998. Geologia e gênese das mineralizações associadas ao maciço Itaoca, Vale do Ribeira, SP e PR. Revista Brasileira de Geociências, v. 28, n. 3, p. 269-284, 1998.

MURATORI, A. Nota explicativa da folha geológica de Campo Largo. Boletim Paranaense de Geociências, v. 21, p. 1-28, 1966.

PEARCE, A. J.; HARRIS, N. B. W.; TNDLE, A. G. Trace Element discrimination for the Tectonic Interpretation of Granitic Rocks. Journal of Petrology, v. 25, p. 956-983, 1984.

PICANÇO, J. L. Composição isotópica e processos hidrotermais associados aos veios auríferos do maciço granítico Passa Três, Campo Largo, PR. 2000, 175 f. Tese (Doutorado) - Instituto de Geociências, Universidade de São Paulo, São Paulo, 2000.

PIEKARZ, G. F. Reconhecimento das Unidades correlacionáveis à seqüência mineralizada do Perau - Estado do Paraná. In: SIMPÓSIO REGIONAL DE GEOLOGIA, 3., São Paulo. Atas... São Paulo: SBG, 1981, v. 1, p. 148-154.
PIEKARZ, G. F. Reconhecimento geológico na região da anticlinal do Setuva / setor ultra metamorfitos. Curitiba: MINEROPAR, 1992.11 p. (Relatório).

PINTO COELHO, C. V; SIEDLECKI, K. N. Aspectos petrográficos e petrológicos do Granito Rio Abaixo - Estado do Paraná - BR. Boletim Paranaense de Geologia, n. 39, p. 19-30, 1991.

PRAZERES FILHO, H. J. Litogeoquímica, Geocronologia (U-Pb) e Geologia Isotópica dos Complexos Graníticos Cunhaporanga e Três Córregos, Estado do Paraná. 2000, 180 f. Dissertação (Mestrado) - Instituto de Geociências, Universidade de São Paulo, São Paulo, 2000.

PRAZERES FILHO, H. J.; HARARA, O. M. M.; BASEI, M. A. S.; PASSARELLI, C. R.; SIGAJUNIOR, O. Litogeoquímica, Geocronologia U-Pb e Geologia Isotópica (Sr-Nd-Pb) das rochas graníticas dos batólitos Cunhaporanga e Três Córregos, na porção sul do Cinturão Ribeira, Estado do Paraná. Geologia USP. Série Científica. v. 3, p. 51-70, 2003.

RENE, P. R. K-Ar and Ar-Ar dating.. In: NOLLER, J. M. S. J. S.; LETTIS, W. R. Quaternary geochronology: methods and applications. Berkley : American Geophysical Union, 2000. p. 77-100. ( Reference Shelf Series, 4).

REIS NETO, J. M. Faixa Itaiacoca: registro de uma colisão entre dois blocos continentais no neoproterozóico. 1994. 253 f. Tese (Doutorado) - Instituto de Geociências, Universidade de São Paulo, São Paulo, 1994.

SALAMUNI, E.; FIORI, A. P.; WERNIK, E. Evolução tectônica e estruturação do Núcleo Betara, arredores de Curitiba - PR. In: CONGRESSO BRASILEIRO. DE GEOLOGIA, 37., 1992, São Paulo. Anais... São Paulo: SBG, 1992, v. 1, p. 280.

SANTOS, M. S.; FELIPE, R. S. Reconhecimento geológico da Faixa Três Córregos. Curitiba: MINEROPAR, 1980. (Relatório Interno).

SIGA JUNIOR, O. Domínios tectônicos do sudeste do Paraná e nordeste de Santa Catarina. Geocronologia e evolução crustal. 1995, 212 f. Tese (Doutorado) - Instituto de Geociências, Universidade de São Paulo, São Paulo, 1995.

SIGAJUNIOR, O.; BASEI, M. A. S.; CURY, L. F.; HARARA, O. M.; SATO, K.; PASSARELLI, C. R. Domínio Apiaí (PR): Registros de Sedimentação do Paleoproterozóico Superior, Mesoproterozóico e Neoproterozóico. In: CONGRESSO BRASILEIRO DE GEOLOGIA, 43., 2006, Aracajú. Anais... Aracajú: SBG, 2006, v. 1.p. 176. 
SILVA, P. C. S.; VASCONCELLOS, C. V. S.; YAMATO, A. A.; PEDREIRA, A. J. O Grupo Açungui na Folha Curitiba (SG22-X-D-I). In: CONGRESSO BRASILEIRO DE GEOLOGIA, 40., 1998, Belo Horizonte, Anais... Belo Horizonte: SBG, 1998, p. 40.

SOARES, P. C. 1987. Seqüências tectono-sedimentares e tectônica deformadora no centro-oeste do Escudo Paranaense. In: SIMPÓSIO SUL-BRASILEIRO DE GEOLOGIA, 3., 1987. Curitiba-PR. Anais...Curitiba: SBG, 1987, v. 1, p. 245-258.

SOARES, P. C.; GÓIS, J. R. Geologia do Granito Passa Três (Paraná) e suas mineralizações auríferas. In: SIMPÓSIO SULBRASILEIRO DE GEOLOGIA, 3., 1987. Curitiba-PR. Anais...Curitiba: SBG, 1987, v. 2, p. 497.

SOARES, P. C.; REIS NETO, J. 1987. Um estudo de caracterização termo-dinâmica de micro-estruturas dos Grupos Açungui e Setuva (PR). In: SIMPÓSIO SUL-BRASILEIRO DE GEOLOGIA, 3., 1987. Curitiba-PR. Anais...Curitiba: SBG, 1987, v. 1, p. $147-165$.

SOARES, P. C.; ROSTIROLLA, S. P. Tectônica de escape tardicolisional nos Cinturões Ribeira e Dom Feliciano. In: SIMPÓSIO NACIONAL De ESTUDOS TECTÔNICOS, 6. 1997, Pirinópolis. Anais...Pirinópolis: SBG, 1997, p. 65-68.

SPOLADORE, A. Caracterização da história deformacional das rochas proterozóicas da região de Bromado, Paraná. 1993. 157 f. Dissertação (Mestrado) - Instituto de Geociências -UNESP, Rio Claro,1993.

VASCONCELOS, P. M.; ONOE, A. T.; KAWASHITA, K.; TEIXEIRA, W. 40Ar/39Ar geochronology at Instituto de Geociências, USP: instrumental, analytical procedures and calibration. Anais da Academia Brasileira de Ciências, v. 74, n. 2, p. 297-342, 2002.

WEBER, W.; SIGAJUNIOR, O.; SATO, K; BASEI, M.A. S.; REIS NETO, J. M. 2003. U-Pb (zircon) ages of metabasic rocks of the Água Clara Formation in the Araçaíba region SP - Brazil: preliminary data. In: SOUTH-AMERICAN SYMPOSIUM ON ISOTOPE GEOLOGY, 4., 2003. Salvador. Extended Abstracts... Salvador: SSAGI, 2003, p. 706-709.

WERNICK, E. Idade da tectônica de colocação do magmatismo granitóide Brasiliano do Estado de São Paulo e áreas adjacentes do Estado de Minas Gerais, SE-Brasil. In: SIMPÓSIO REGIONAL DE GEOLOGIA, 5., 1997, São Paulo. Atas... São Paulo: SBG, 1997, v. 1, p. 104-106.

WERNICK, E. Estágios de magmatismo granitóide no
Cinturão Ribeira (Ciclo Brasiliano). In: CONGRESSO BRASILEIRO DE GEOLOGIA, 40., 1998, Belo Horizonte. Anais... Belo Horizonte: SBG, 1998a, p. 22.

WERNICK, E. Feições do magmatismo granitóide no Cinturão Transpressivo Ribeira (Ciclo Brasiliano). In: CONGRESSOBRASILEIRODE GEOLOGIA, 40., 1998, Belo Horizonte. Anais... Belo Horizonte: SBG, 1998b, p. 28. 